\title{
Study on Corporate Governance Optimization Considering Power Enterprise Mixed Ownership System Reform
}

\author{
Zhaoyang $X u^{1, *}$, Feng Ye ${ }^{1}$, Shaohong Zou ${ }^{1}$, Yuan Wang ${ }^{2}$, Qiushuang $W^{2} i^{2}$, and Yu Yin ${ }^{2}$ \\ ${ }^{1}$ Zhejiang Electric Power Industry General Corporation, Zhejiang 310008, China \\ ${ }^{2}$ North China Electric Power Univ., Beijing 102206, China
}

\begin{abstract}
Mixed ownership system reform is the focus of current state asset reform, and the reform efficiency of power enterprise attracts worldwide attention. This paper discusses the mixed ownership system reform of power enterprise from the angle of corporate governance. First of all, this paper will analyze the corporate governance situation and existing problems from ownership structure and other two aspects. Second, the corporate governance model of power enterprise is constructed. Third, governance optimization measures will be put forward and the conclusion is obtained. This paper hopes to provide certain reference for corporate governance of mixed ownership system reform of Chinese power enterprises.
\end{abstract}

\section{INTRODUCTION}

Chinese economy system reform lasts for more than 30 years, in this period, state asset enterprise reform remains at the most important place, and power enterprise reform attracts corresponding attention which plays an important role in state economic lifeline and energy security. Opinions about Deepening State-owned Enterprise Reform issued on 2015 took "Mixed Ownership Economy Development" as the first target, which makes mixed ownership system reform the priority of state asset reform. Mixed ownership economy has various advantages, such as integration and development of state capital, collective capital and nonpublicly-owned capital, enhancing the competitiveness and the maintenance and appreciation of state asset, and stable social development. In this basis, we need to know the influencing factors of power enterprise corporate governance, find out existing problems and put forward corresponding optimization measures to form more efficient and reasonable corporate governance structure and contribute to competitive modern enterprise[1].

\section{CORPORATE GOVERNANCE SITUATION AND POWER ENTERPRISE}

Corporate governance was generated after separation of ownership and management right of enterprise, and it stands at the point of enterprise ownership, researches the authority mode, range and strength of professional manager, and efficiently supervises manager's behaviors. Current power enterprise plays an important role in stateowned enterprise and has formed the diversified ownership structure composed by state-owned holding and other subsidy shareholding ways. It has the board of directors system and the board of supervisors system, which create certain efficiency and some problems, including unreasonable ownership structure, principalagent issues, party and government intervention and imperfect corporate governance structure.

\subsection{Unreasonable ownership structure}

Premier Li Keqiang's government work report on May 5 , 2017 highlighted the significance of state asset reform, establishing efficient corporate governance structure and basically completing the corporation system reform. And Chinese ownership system reform was begun during Third Plenary Session of the 11th Central Committee of the Chinese Communist Party. Power enterprise now has established diversified ownership structure and the publicly-owned capital exists with non-publicly-owned capital in power enterprise. However, ownership structure change doesn't change some problems of power enterprise: state-owned ownership is always the powerful shareholder, non-state-owned ownership cannot restrict and supervise the state-owned ownership and its benefit cannot be guaranteed[2]. Obviously, stateowned capital plays an significant role in corporate governance, and the old management model of it has dealt a great blow to the enthusiasm of non-public capital to enter the power enterprises, which goes against advantages of non-public capital and the requirements of ownership system reform. Besides, there is still a serious monopoly in the power industry, that creates excess profit for state-owned power enterprise and the enter barriers is built for publicly-owned capital.

\subsection{Serious principal-agent issues}

\footnotetext{
* Corresponding author: author@e-mail.org
} 
Follow Figure 1 shows the principal-agent chain of power enterprise. It can be seen that the basic owner of Chinese power enterprise is all people and the terminal agent is the manager of power enterprise. However, people cannot directly supervise the operation situation of power enterprise and state-owned capital management institution is the one has the real supervision right. This kind of institution supervises representatives of power enterprises with human resource management, but numerous of enterprises and their various structures weaken the supervision right of state-owned capital management institution. Then serious principal-agent issues are generated.

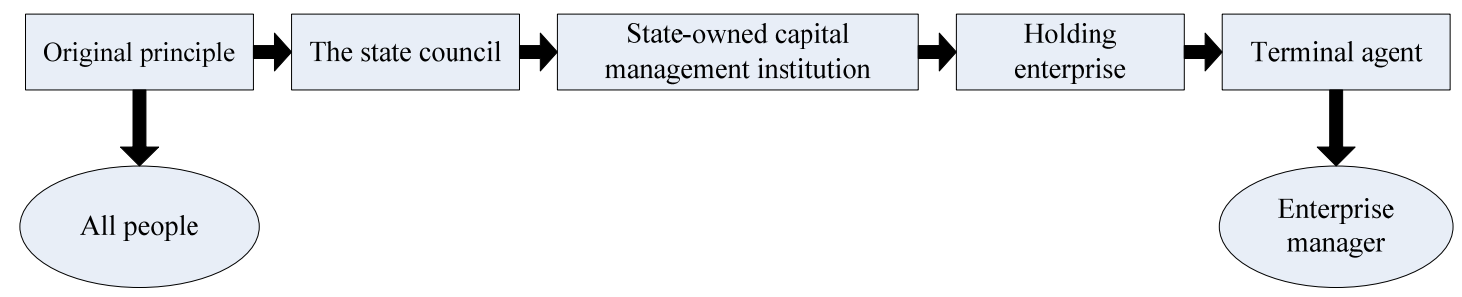

Figure 1. Principal-agent chain of power.

\subsection{Party and government intervention}

Chinese government manages the capital of power enterprise with "state-owned capital management chain" and controls the management and the operation of power enterprise with human resource and assessment system. In this basis, enterprise system reform doesn't truly separate the ownership from the management right of power enterprise. What's more, current party and government officials have certain administrative levels, these go against requirements of mixed ownership system reform, and power enterprise cannot get rid of old system restriction, cannot attract high quality management personnel, and cannot truly benefit from mixed ownership system reform.

\section{OPTIMIZATION MEASURES OF POWER ENTERPRISE CORPORATE GOVERNANCE}

From Section 2 of this paper, we know that various problems are existing in mixed ownership system reform of power enterprise, and that's why Chinese power enterprise cannot satisfy requirements of mixed ownership system reform[3]. Mixed ownership system reform allows the publicly-owned capital exist with nonpublicly-owned capital, based on this, the ownership allocation between publicly-owned capital and nonpublicly-owned capital and the ownership structure optimization appear to be particularly important[4]. There are four main levels of corporate governance: shareholders' meeting, board of directors, board of supervisors and manager. The shareholders' meeting exercises the functions of shareholders and consist of state-owned capital investment enterprises; The board of directors exercises the decision-making function and is composed of representatives elected by the general meeting of shareholders; The board of supervisors exercises the supervisory function, and is composed of supervisors and staff representatives elected by the shareholders' meeting; The manager exercises management the function and is appointed by the board of directors and is responsible for the board of directors. Meanwhile, State-owned Assets Supervision and Administration Commission also exercises the supervisory function. The corporate governance model of power enterprise of mixed ownership is showed in following Figure 2.

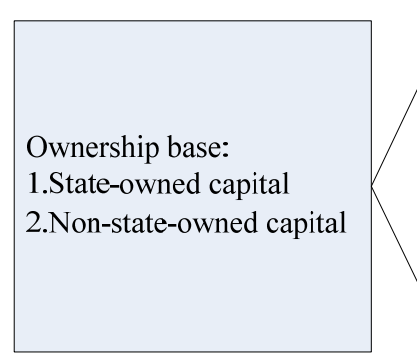

Corporate governance structure:

1. Shareholders' meeting

2. Board of directors

3. Board of supervisors

4. Manager

Governance system:

1.Ownership encouragement

2.Control and supervision

3.Performance evaluation

4.Management appointment

5.Information disclosure
Corporate governance optimization:

1. Ownership structure optimization

2. Human resource system optimization

3. De-administration management of executives

4. Establishing reasonable capital

entry and exit guarantee mechanism

Figure 2. Corporate governance model of power enterprise of mixed ownership

From the corporate governance structure model of mixed ownership system, it can be inferred that the corporate governance mechanism mainly includes ownership encouragement, control and supervision, performance evaluation, management appointment and information disclosure[5]. Therefore, corresponding optimization methods of corporate governance are ownership structure management, human resource 
system optimization, de-administration management of executives and establishing reasonable capital entry and exit guarantee mechanism.

\subsection{Ownership structure optimization}

Mixed ownership reform of power industry is designed to attract more creditworthy and powerful non-stateowned capital investors to improve the enthusiasm of non-state-owned capital, optimize corporate governance structure of power enterprise, strengthen the supervision and restriction function, and improve the operation ability, profit ability and development ability of power enterprise. Current key point of mixed ownership system reform is the ownership structure optimization and increase the proportion of non-state-owned capital in total capital. How should the non-state-owned capital enter the power enterprise and what is the best proportion should be determined by enterprise characters. As to the important task of power generation and transmission and distribution, power enterprise is different from the competitive companies such as manufacturing and services, and it belongs to functional enterprise, its main role is to complete certain strategic objectives according to the national requirements. In order to ensure its proper functioning, the optimal ownership structure is the relative holding of stateowned capital and the participation of non-state-owned capital. In the allocation relation of ownership and control right, it is important to ensure that state-owned capital has relative ownership and non-state-owned capital has relative control right. This kind of ownership allocation mode uses unique advantages of state-owned capital to improve operation efficiency and competitiveness, enables non-state-owned capital to obtain more benefits from the relative monopolistic advantages of power enterprises, and realizes the mutual benefit of state-owned capital and non-state-owned capital.

\subsection{Human resource system optimization}

The ownership cannot guarantee corresponding right in operation management of non-state-owned capital, so to avoid mixed ownership reform become a mere formality, after optimizing the ownership structure, the next step is to optimize the human resource system. Based on the corporate governance structure in Figure 2, the board of directors is composed of directors, who are in charge of the internal affairs and external decision-making businesses of the enterprise. In the board of directors, non-state-owned capital representatives should be elected in a certain proportion to ensure its certain decision-making power to protect the interests of the non-state-owned capital investors and increase the initiative of the non-state-owned capital to enter the power industry. Besides, the board of supervisors includes representatives of the board of directors and worker representatives, due to the natural advantages of state-owned capital in power enterprise, the composition of the board of supervisors should increase the proportions of non-state-owned capital investors and worker representatives to balance the state-owned capital and the non-state-owned capital. In addition, state-owned capital management institution should let go of the manager appointment right, and the board of directors should introduce qualified professional manager and establish reasonable performance evaluation and encouragement system.

\subsection{De-administration management of executives}

In state-owned enterprise and enterprise with stateowned capital, some executives have their political identity, this situation leads to discourse right inequality between interest representatives of state-owned capital and non-state-owned capital, and the inequality won't be able to protect the interests of the non-state-owned capital investors and also can't put the advantages of mixed ownership system into full play. To change this situation, de-administration management of executives should be established, management representatives of state-owned capital and non-state-owned capital should have equal positions, party intervention should be weakened, executive appointment should be controlled by the board of directors based on market rules, professional managers with advanced operation experience, excellent personality and management ability should be introduced to let the power enterprises get new vigor and vitality in the reform of mixed ownership system.

\subsection{Establishing reasonable capital entry and exit guarantee mechanism}

Fair and reasonable and competitive market environment is the cornerstone of the maximum utility of corporate governance mechanism. Therefore, equal market environment and competitive opportunity should be provided for state-owned capital and non-state-owned capital. State-owned capital in competitive market will fully supervise the market, perfect the corporate governance of power enterprise in the development of the mixed ownership reform, enhance its competitiveness, and improve the management efficiency and benefits. While safeguarding the competitive environment, reasonable capital entry and exit guarantee mechanism for non-state-owned capital should be established. As one of functional enterprises, the relative holding status of state-owned capital should be determined and reasonable capital entry and exit guarantee mechanism shoulder be built. Specifically, for the entry mechanism, non-public-owned capital can enter the power enterprises with enterprise acquisition, asset restructuring and equity transfer. For the exit mechanism, the non-public-owned capital can exit the operation and management of the power enterprises in the form of repurchasing or transferring of ownership, profit distribution, etc. Power enterprise should optimize its corporate governance structure and mechanism, establish capital entry and exit guarantee mechanism 
considering external supervising system, and attract nonpublic-owned capital.

\section{CONCLUSIONS}

Chinese mixed ownership system reform brings both opportunities and challenges for power enterprise. Changing inherent economic system, breaking the monopoly situation of state-owned capital, effectively attracting non-public-owned capital and ensuring its reasonable position are problems worth thinking by power enterprise in mixed ownership system reform. In mixed ownership system reform, the power enterprise should optimize the corporate governance model from three aspects, including ownership base, corporate governance structure and corporate governance mechanism, and explore the mixed ownership system reform path considering the characteristics of China's national conditions.

This paper firstly analyzed corporate governance situation of power enterprise and discussed a series of questions: unreasonable ownership structure, principalagent issues, party and government intervention, etc. Secondly, the corporate governance model of power enterprise was put forward and corresponding optimization measures was provided: ownership structure management, human resource system optimization, de-administration management of executives and establishing reasonable capital entry and exit guarantee mechanism. In conclusion, power enterprise should introduce non-public-owned capital, establish reasonable capital entry and exit guarantee mechanism, and provide full discourse right for nonpublic-owned capital based on ensuring the position of state-owned capital, and all of these can be obtained by de-administration management of executives, composition of the board of directors and manager appointment. Measures in this paper ensures the relative control right of state-owned capital and improves competitiveness of power enterprise by using advanced operation theory and flexible operation model of nonpublic-owned capital.

\section{References}

1. 1. X.Yin, W.Li, L.Wu, et al.. Nankai Business Review, 18, 6, pp:146-153 (2015).

2. F.Hu. Journal of Hunan Administration Institute, 6, pp:76-82 (2016).

3. C.Zhang. Times Finance,3,pp:35-41 (2017).

4. W.Liu, Z.Cao. Coal Economic Research | Coal Econ Res, 36,10, pp:22-25 (2016).

5. H.Yang, L.Tong. Macroeconomics, 1,pp: 42-51 (2015). 